(昭和 54 年 5 月 30 日受理)

\title{
繊維層フィルターチップの通気抵抗*
}

\author{
日本専売公社中央研究所 前 田 和 生 - 安斎由和子
}

\section{PRESSURE DROP ACROSS THE FIBROUS FILTER TIP}

\author{
By Kazuo Maeda and Yuriko Anzai
}

(The Central Research Institute, Japan Tobacco \& Salt Public Corporation, 6-2 Umegaoka, Midori-ku, Yokohama)

The pressure drop of randomly packed fibrous filter tips for cigarette smoke was studied to establish the relation with the filter properties; kinds of fiber, fiber denier per filament, cross section of fiber, volume fraction of fiber, weight fraction of fibers and filter making method.

On the basis of linear relations found between modified permeability coefficient calculated with equations (2)-(4) and a porosity function, the pressure drop across the fibrous filter tip is given as

$$
\Delta P=k \frac{\eta L v}{d^{2}{ }_{\mathrm{fm}} g \rho}\left(1-\varepsilon_{\mathrm{f}}\right)^{n}
$$

where the resistance coefficient $k=70$ and exponent $n=1.92$ for the model filter. The $k$ value depends on the structural arrangement of the fiber in the filter tip.

(Received May 30, 1979)

\section{1. 緒言}

たばこ電用フィルターとして多数の沪材が検討されて きたが、市販のフィルターは，大部分がアセテート䄉維 を沪材とし，一部に紙，パレプ，羊毛が用いられている。 その他，活性炭，イオン交換樹脂，無機吸着風などが複 合フィルター用添加物として使用されているに過ぎない。 これらの沪材のフィルター成形法についても多数の考案 がなされてきたが，アセテート瀻維の場合は捲䙋のかけ られた織維束を開繊し可塑剂を添加後，巻取紙で巻上げ るトウ方式りより，緍，パルプ，羊毛の場合は，それ ぞれクレープ紙の巻上 ${ }^{2}$, パルプ不織布のS字成形後の 巻上 ${ }^{3)}$ ，羊毛の帯状成形後の巻上“によっている。その 他，不織布 ${ }^{5)}$, スライバ一及び短織維 ${ }^{6)}$ の巻上成形法な どる開発されている。

一方，たばて煙用フィルターの性能は，たばとの香製 味に与える影響のほか，エアロゾル用フィルターの場合 と同椂に，フィルターの通気抵抗と煙成分の沪過効率に よって評価されている。新フィルタ一の開発あるいは設

*この報文を「たばと煙用フィルターに関する研究(第 13 報), Studies on the Filter for Cigarette Smoke (Part 13)」とする。
計上の立場からいえば，いずれの沪材，成形法を用いる 場合でも，沪材の段階で成形品の性能が推定できること が望ましいてとから，筆者らは，緎維層フィルターチッ プの通気抵抗及び沪過効率之瀻維の種類、纎維径、断面 形状，充填量，繊維配列，成形方法，チップの長さなど のフィルター棈成要因との間の関倸について検討してき t。

本報では，䋞維層フィルターチップの通気抵抗に及ぼ す繊維の種類，単系瀻度，断面形状，充填量，成形方法 などの影響について，簡単に手つくくりできるつィルター チップを用いて害験的な検討を加え，二，三の知茪を得 たので報告する。

\section{2. 実}

\section{1 試 料}

レーヨン織維及びポリプロピレン綪維は市販品を使用 した。ビニロン繊維はクラレ(株)の提供品を使用した。 アセテート維維はダイセル(株)及び三菱アセテート（株） で製造された捲縮済の緎維束を使用したほか三菱了セテ ート(株)で試製された断面形状の異なる 4 デニールの末

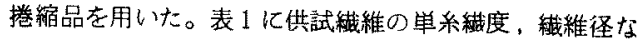
どの諸特性值をまとめて示す。 
Table 1 Properties of testeu ribers

\begin{tabular}{|c|c|c|c|c|}
\hline Kinds of fiber & $\begin{array}{c}\text { Denier } \\
\text { per } \\
\text { filament }\end{array}$ & $\left(\mathrm{g} / \mathrm{cm}_{\mathrm{f}}\right)$ & $\begin{array}{l}d_{\mathrm{f}}^{* 1} \\
{[\mu \mathrm{m}]}\end{array}$ & $\begin{array}{l}\text { Cross-section } \\
\text { of fiber }\end{array}$ \\
\hline Rayon & $\left\{\begin{array}{l}0.8 \\
1.5 \\
3.0 \\
7.0\end{array}\right.$ & $\begin{array}{c}1.54 \\
" 1 \\
\prime \prime \\
\prime \prime\end{array}$ & $\begin{array}{r}8.6 \\
11.8 \\
16.6 \\
25.4\end{array}$ & $\begin{array}{c}\text { Regular } \\
\text { " } \\
\text { " } \\
\text { " }\end{array}$ \\
\hline Vinylon & $\left(\begin{array}{l}1.5 \\
3.0\end{array}\right.$ & $\begin{array}{c}1.26 \\
\prime \prime\end{array}$ & $\begin{array}{l}13.0 \\
18.4\end{array}$ & $\underset{\prime \prime}{\text { Regular }}$ \\
\hline Polypropylene & 3.0 & 0.90 & 21.7 & Regular \\
\hline Acetate $^{* 2}$ & $\left\{\begin{array}{l}1.7 \\
1.9 \\
2.2 \\
2.5 \\
3.3 \\
4.0 \\
8.0\end{array}\right.$ & $\begin{array}{c}1.32 \\
" \\
" \\
" \\
" \\
" \\
"\end{array}$ & $\begin{array}{l}13.5 \\
14.3 \\
15.4 \\
16.4 \\
18.8 \\
20.7 \\
29.3\end{array}$ & $\begin{array}{l}\mathrm{Y} \\
" \\
" \\
" \\
" \\
" \\
"\end{array}$ \\
\hline Acetate & $\left\{\begin{array}{l}4.0 \\
4.0 \\
4.0 \\
4.0 \\
4.0\end{array}\right.$ & $\begin{array}{c}1.32 \\
" \\
" \\
" \\
"\end{array}$ & $\begin{array}{c}20.7 \\
" \\
" \\
" \\
"\end{array}$ & $\begin{array}{l}\text { Regular } \\
\mathrm{Y} \\
\lambda \\
\mathrm{I} \\
\mathrm{H}\end{array}$ \\
\hline
\end{tabular}

${ }^{* 1} d_{\mathrm{f}}=11.91 \sqrt{d / 0_{\mathrm{f}}},{ }^{* 2}$ Crimped

\section{2 試料の調製}

モデルフィルター(ランダム充填方式)は，供試较維を $3 \mathrm{~mm}$ 前後に切断し，果実シュース用ミキサーで解瀻し 均一な綿状とした後、一定量を内径 $0.77 \mathrm{~cm}$ ，長さ 1.7 $\mathrm{cm}$ のアクリル製円管内に充填し、両端をナイロンネッ トで覆い，セロハンテープで固定して作成した。

アセテートフィルター(トゥ方式)は，織維束を正縮空 気及びロールで開緎し，トリアセチンを7\%添加後，円 周 $2.47 \mathrm{~cm}$ に紙巻して製造されたフィルタープラグを所 定長さに切断して用いた。

不織布フィルター(シート方式は、1〜2インチの供 試轱維をつィダー及びカードマンンで混合し，ウェブを 形成し，とのウェブにポリビニルアルコール及びポリメ タタリル酸ブチル系結合剂を浸漬法で添加し，圧搾後乾 燥し, 厚さ $0.5 \mathrm{~mm}$, 坪量 $45 \sim 50 \mathrm{~g} / \mathrm{m}^{2}$ の不織布を得た。 この不織布を $16 \mathrm{~cm}$ 幅で帯状に裁断し，次にリボン状に 5 等分した後, 円周 $2.47 \mathrm{~cm} に$ 紙巻してフィルターとし た。

レーヨンフィルター(スライバー方式)は，レーヨン䋐 維を集束し，浸漬法でポリ酢酸ビニル系結合郕を添加し 畭燥後，そのまま円周 $2.47 \mathrm{~cm}$ 亿紙巻し，所定長さ汇切 断してフィルターとした。

\section{3 測定方法}

測定は，温度 $20 \pm 1 \mathrm{C}$ ，相対湿度 $60 \pm 2 \%$ の調和室内 で行なった。

フィルターチップの通気抵抗 $\Delta P$ は，試作の自動通気
抵抗測定器 ${ }^{7)}$ 使用し，チップに 17.5 $\mathrm{ml} / \mathrm{sec}$ の空気を通したとき，入口と 出口で生じる圧力差を測定し水柱の高 さで表示した。

克填率 $\left(1-\varepsilon_{f}\right)$ は, (1)式で算出し, 緎 維の密度 $\rho_{\mathrm{f}}$ は，文献值及びBeckman 架気比較式比重計で測定した值を用い た。

$$
\left(1-\varepsilon_{\mathrm{f}}\right)=W / \rho_{\mathrm{f}} V
$$

紻維径 $d_{\mathrm{f}}$ は，䄉維断面を中形亡仮定 し, 単系緎度 $d$ から(2)式で算出した。

$$
d_{\mathrm{f}}=11.91 \sqrt{d / \rho_{\mathrm{f}}}
$$

織維断面の形状係数 $\emptyset_{\mathrm{f}}$ は, 繊維の周 辺長 $l$ を内周之する円の面皘之䄉維断 面皘 $s$ とから(3)式で算出した。

$$
\Phi_{\mathrm{f}}=l^{2} / 4 \pi s
$$

$l$ 及び $s$ は，繊維をワックスで团定後， ミクロトームで切断し，繊維断面の顕 微鏡写真を撮影し、てれから無作為に 10 本の緘維を選び, キルビメーター 及びプラニメーターで求めた。

繊維の修正瀻維径 $d_{\mathrm{fm}}$ は, $d_{\mathrm{f}}$ 及び $\Phi_{\mathrm{f}}$ から (4) 式で算出 した。

$$
d_{\mathrm{fm}}=d_{\mathrm{f}} / \sqrt{\Phi_{\mathrm{f}}}
$$

\section{3. 実験結果}

\section{1 絤維の種類}

レーヨン．ビニロン及びポリプロピレンの 3 種類の織 維について，充填率を变えてモデルフィルターチップの 通気抵抗を測定した。結果を画対数グラフ上にプロ，卜 し、図1亿示す。

フィルターチップの通気抵抗は繊維充填率の 1.5 2.3 乗に比例しているととが認められた。また同じ単系緎度 の㵶維でも種類によって通気抵抗が異なり、レーヨン絿 維では高く，ポリプロピレン瀻維では低いととが認めら れた。

\section{2 单米䋊度}

単系緎度の異なるY断面アセテート瀻維の緎維充填率 とチップ通気抵抗の関係を图 2 亿示す。

アセテート繊維の単系織度が小さいはど同一充填率に おりるチップの通気抵抗は高く，また単系繊度が小さい はど勾配が緩やかであるととが認められた。

\section{3 断面形状}

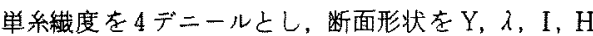
及びRegular 断面としたアセテート紴維の充填率とチッ プ通気抵抗の関係を园 3 に示す。 


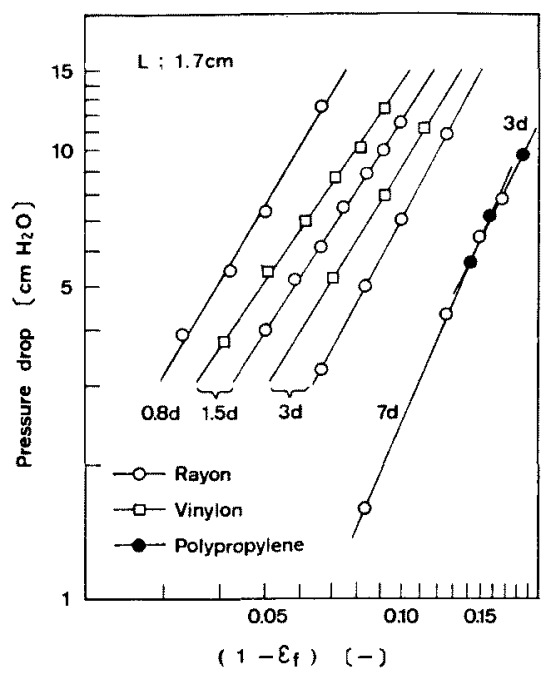

Fig. 1 Influence of the kinds of fiber on the pressure drop

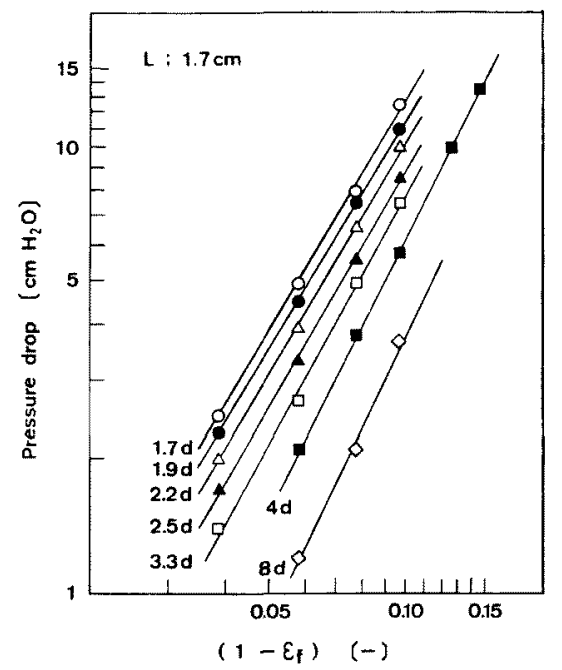

Fig. 2 Effect of the filament per denier of acetate fiber on the pressure drop

チップの通気抵抗は, 繊維の断面形状によって異なり，

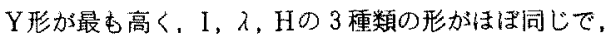
Regular 形加低加った。

次に緎維断面の形状係数の測定結果を表 2 及び图 4 に 示す。

表 2 及び図 3 から明らかなようにフィルターチップの 通気抵抗は絨䧽断面の形状係数が大きくなると高くなる

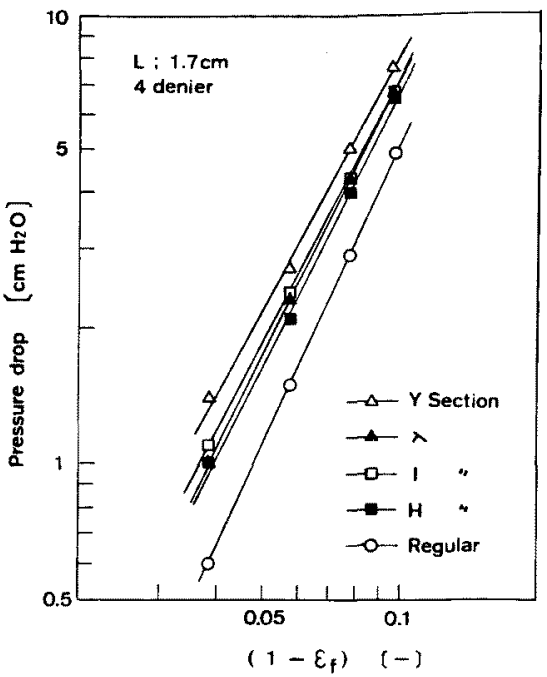

Fig. 3 Effect of the cross-sections of acetate fiber on the pressure drop

Table 2 Shape factors of tested fibers

\begin{tabular}{lcc}
\hline Kinds of fiber & $\begin{array}{c}\text { Filament per } \\
\text { denier }\end{array}$ & $\begin{array}{c}\text { Shape factor } \\
{[-]}\end{array}$ \\
\hline Rayon & 3 & 1.89 \\
Polypropylene & 3 & 1.30 \\
Vinylon & 3 & 2.40 \\
Acetate Y Section & 4 & 3.46 \\
" $\lambda$ " & " & 3.23 \\
" I " H " & " & 3.01 \\
" Regular & " & 3.23 \\
\hline
\end{tabular}

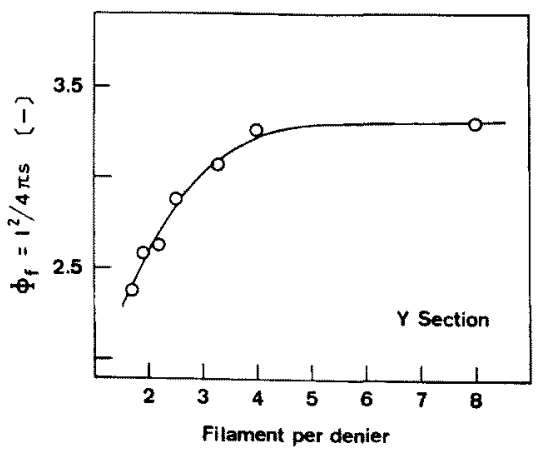

Fig. 4 Change in the shape factor with the filament per denier of $Y$ section acetate fiber 
Table 3 Pressure drop of two-component filter tip

\begin{tabular}{|c|c|c|c|c|}
\hline Filter composition & \multirow{2}{*}{$\begin{array}{c}\begin{array}{c}\text { Weight } \\
\text { fraction } \\
{[-]}\end{array} \\
0.5 \\
0.5\end{array}$} & \multirow{2}{*}{$\begin{array}{c}\begin{array}{c}\text { Volume } \\
\text { fraction } \\
(-]\end{array} \\
0.0405\} 0.081 \\
0.0405\end{array}$} & \multicolumn{2}{|c|}{$\begin{array}{l}\text { Pressure drop } \\
\left.\text { (cm } \mathrm{H}_{2} \mathrm{O}\right] \\
\text { Calcd. Exptd. }\end{array}$} \\
\hline $\begin{array}{ll}\text { Vinylon } & 1.5 \mathrm{~d} \\
\text { Vinylon } & 3 \mathrm{~d}\end{array}$ & & & 8.5 & 9.0 \\
\hline $\begin{array}{l}\text { Vinylon } 1.5 \mathrm{~d} \\
\text { Acetate } 4 \mathrm{~d}\end{array}$ & $\begin{array}{l}0.5 \\
0.5\end{array}$ & $\left.\begin{array}{l}0.0405 \\
0.0386\end{array}\right\} 0.079$ & 7.1 & 7.5 \\
\hline $\begin{array}{ll}\text { Vinylon } & 1.5 \mathrm{~d} \\
\text { Rayon } & 0.8 \mathrm{~d}\end{array}$ & $\begin{array}{l}0.5 \\
0.5\end{array}$ & $\left.\begin{array}{l}0.0405 \\
0.0331\end{array}\right\} 0.074$ & 11.9 & 11.8 \\
\hline $\begin{array}{l}\text { Vinylon } 3 \mathrm{~d} \\
\text { Acetate } \\
\text { 4d }\end{array}$ & $\begin{array}{l}0.5 \\
0.5\end{array}$ & $\left.\begin{array}{l}0.0405 \\
0.0386\end{array}\right\} 0.079$ & 5.2 & 5.5 \\
\hline
\end{tabular}

バー方式及びランダム充填方式で作成し たフィルターチップの通気抵抗と，単系 瀻度 4 デニール，Y断通のアセテート瀻 維を使用し，卜ウ方式，シート方式及び ランダム充填方式で作成したフィルター チップの通気抵抗を四 5 亿示す。

フィルターチップの通気抵抗は同じ緎 維を一定の充填率で成形した場合でむ成 形方法に上って大きく異なるこ上が認め られた。

\section{4. 考察}

䋐維層フィルターの王力損失に関する理諭的取扱いは, 従来の次元解析，抗力理論比よるもの上構造的研究に上 るるのがある。

なばて煙用フィルターの場合は，瀻維の充填率が 0.1 前後,フィルター断面積が約 $0.5 \mathrm{~cm}^{2}$, チップの長さが 0.7 $\sim 3 \mathrm{~cm}$, 通過流量が $17.5 \mathrm{ml} / \mathrm{sec}$ ，したがって通過流速 か $40 \mathrm{~cm} / \mathrm{sec}$ 前後，瀻維は異形断面，綪維配列は流れ に水平側に近い構造などの特徵をむつがの通気抵抗

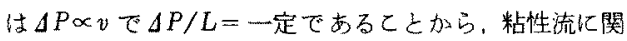
するDarcyの式が成立する ${ }^{193}$ 。

$$
\triangle P=k L \mu v
$$

そてで, 図1，2で得られた結果を用いてフフィルター チップの充填率に対する通気抵抗を(7)式に示すDavies の透渦保数 $K^{9)}$ を用いて整理したが，瀻維径の買なるレ ーヨン繊維の場合にはほぼ一本の直線上にプロットされ たが各瀻維間で比較するとまとまりがよいとはいえなか った ${ }^{10)}$ 。こてで問題となるのは $d_{1}$ の决め方である。従 来の研究で用いられた緎維は主として円形断面のガラス 䋐維であって、算術平均径あるいは体面皘平均径で解析 がなされている。Davies ${ }^{{ }^{9}}$ はる算術平均径を用いて(7) 式を導いた。

$$
K=\frac{\Delta P d_{i}^{2}}{\eta L v}=64\left(1-\varepsilon_{f}\right)^{15}\left[1+56\left(1-\varepsilon_{\mathrm{f}}\right)^{3}\right]
$$

Clarenburgらは(8)式を実験的に得だ ${ }^{11)}$ が、ガラス 䄉維の配置をMonte Carlo法で行ない，それによってで き万䋲目構造の細孔心相当直径を求如，電子顕微鏡写真 から求めた場合と同様に対数正規分布をなすことを確認 した ${ }^{12)}$ 。

$$
K=180 C^{-25} \cdot\left(1-\varepsilon_{f}\right)^{1.5}
$$

Kozeny-Charman ${ }^{13)}$ は, 沪材の比表面積 $S^{2}$ が $\Delta P$ K 比例するとして水力相当直径の考方方加的空腙率関数を 求めた。。

$$
K=k\left(1-\varepsilon_{\mathrm{f}}\right)^{2} / \varepsilon^{3}
$$

(9)式は空隚率の大きいとき誤差の大きいとと加ら，織

Fig. 5 Influence of filter making methods on the pressure drop 
維充填層に適用するととは邀切とはいえない出。

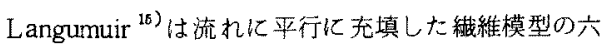
角形セルに相当する円管を考えて(10)式を導いた。

$$
K=\frac{1.4 \times 4\left(1-\varepsilon_{\mathrm{f}}\right)}{-\ln \left(1-\varepsilon_{\mathrm{f}}\right)+2\left(1-\varepsilon_{\mathrm{f}}\right)-\left(1-\varepsilon_{\mathrm{f}}\right)^{2} / 2-3 / 2}
$$

Chen ${ }^{16)}$ はフィルターを構成する織維の配置構造に依 存するとして(11)式を提案した。

$$
K=k\left(1-\varepsilon_{\mathrm{f}}\right) / \varepsilon_{\mathrm{f}}
$$

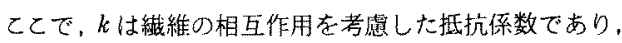
$d_{t}$ こしては体面積平均佳を用いた。

木村ら ${ }^{17)}$ は，非円形断面蟣維，すな力ら力ネ力ロン、ビ ニロン，綿などの䋐維について絨維断面形状係数 $\phi_{\mathrm{f}}$ を導

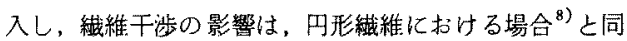

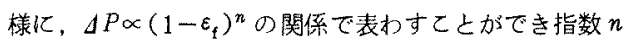
は $d_{\mathrm{f}}$ のはかに $\phi_{\mathrm{f}}$ の関数となることを示した。

$$
\begin{aligned}
& \phi_{\mathrm{f}}=4 \mathrm{~s} / \pi l_{0}^{2} \\
& n=1.60 d_{\mathrm{f}}^{-0.05} \phi_{\mathrm{f}}^{-0.1 \mathrm{~s}}
\end{aligned}
$$

しかし繊維が流れに垂值とみなす抗力理論による理諭式 あるいは实験式を、緎維をランダムに无填したフィルタ 一チップに適用することには問題がある。また木村らの

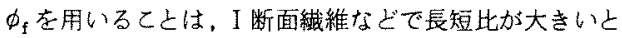
き誤差の大きくなるとと加ら適切とはいえない。

以上のととから，繊維径あるいは繊維断面形状により フィルターチップの通気抵抗が買なる原因として沪材の 表面皘の影響 ${ }^{13}$ を考慮しなけ扎ばならない。そとで供試 緎維の断面写真を撮り，断面皘 $s$ 之断面の周辺長 $l$ 上を 測定した。実測した瀻維のsとしのバラッキはかなり大 きかったので面皘補正をした繊維断面の形状係数 $\Phi_{\mathrm{f}}$ を (3)式から求めた。なおこの毛は Shape factor $l^{2} / s$ を用いると，真円の場合の Shape factor $4 \pi=12.57$ 之

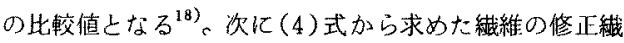
維径 $d_{\mathrm{fm}}$ を無次元化した (7)式に導入した。レーヨン及 びビニロン緎維の $\Phi_{\mathrm{f}}$ は，Y断面のアセテート繊維で認め られた単系織度の影嘅が小さい屯のと考元，表 2 に示し

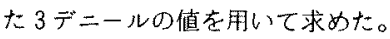

$$
K_{\mathrm{m}}=\frac{\Delta P d_{\mathrm{fm}}{ }^{2} g \rho}{n L v}=k\left(1-\varepsilon_{\mathrm{f}}\right)^{n}
$$

図1〜3で明らかなように，瀻維層フィルターチップ の通気抵抗は瀻維充填率の $n$ 乗に比例して变化すること 汃ら，得られた全てのデータを用いて，繊維充填率に対 して修正透调係数 $K_{\mathrm{m}}$ 在プロットした。その結果は図 6 に示すように笚系㵶度，断面形状などの異なる全ての緎 維がほほ1本の直線上にまこめられ，(14)式の成立する ことが確かめられた。ランダム充填方式のモデルフィル ターでは $k=70, n=1.92$ が求められた。ここで，kは㵶

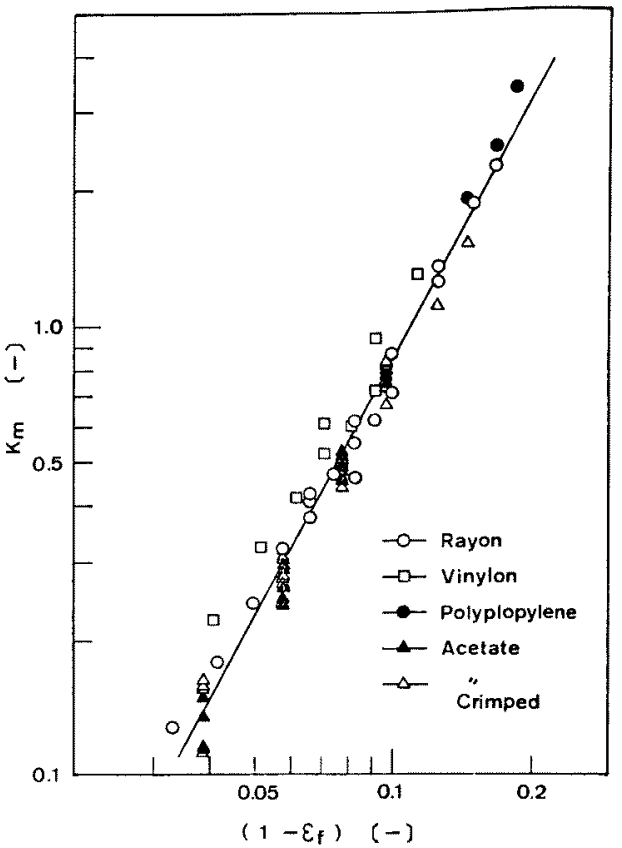

Fig. 6 Relationship between the modified permeability coefficient and the packing density of filter tips

維の配列，配向などのフィルターの構造にもとつく係数 であって, 図 5 から明らかなようにフィルターチップの 成形方法によって異なる。沪材の使用量という観点加ら はにの大きな成形方法が望ましいと考えられ、シート方 式，卜ウ力式及びスライバー方式による成形方法は，う ンダム充填方式に比べて改良の余地があるといえる。次 に指数れは1.92という值が得られたが、この值は流れに 垂直に配列したガラス䋐維で得られた約 $1.5^{*, 11,17)}$ に比 ベてやや大きく，粒子状物に水力相当直径の考え力を適

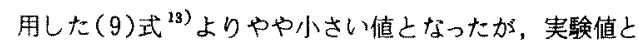
してはほぼ妿当な值と考えられる。

したがって，モデルフィルターチップの通気抵抗を求 める実験式は(15)式で示された。

$$
\Delta P=70 \cdot \frac{\eta L v}{d_{\mathrm{fm}}^{2} g \rho} \cdot\left(1-\varepsilon_{\mathrm{f}}\right)^{122}
$$

成形方法がモデルフィルターと異なる場合は、あらかじ めモデルフィルターよの比較係数を求わておき，との值 を乗ずるととによって、䋐維の種類、纎度、断面形状な どの異なる繊維層フィルターチップの通気抵抗の推定が 可能である。さらに推定精度を上げるためには，䋞維の

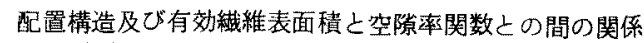
をより明確にする必要があると考えられる。 


\section{5. 結論}

たばこ煙用瀻維層フィルターチップの通気抵抗と瀻維

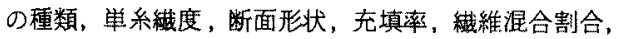
成形方法などのフィルター構成要因との間の関係につい て明ら加にすため実験的な検討を行なった。

繊維が流れ方向に対しランダムに配㯰したモデルフィ ルターチップについて，(2)〜（4)式を導入した修正透 過係数之空隚率関数との間に直線関係が認められたと上 から、繊維層フィルターチップの通気抵抗は次のような 実験式で示された。

$$
\Delta P=k \cdot \frac{\eta L v}{d_{\mathrm{fm}}^{2} g \rho} \cdot\left(1-\varepsilon_{\mathrm{f}}\right)^{n}
$$

モデルフィルターでは，抵抗係数 $k=70$, 指数 $n=1.92$ が求められ， $k$ は成形方法の相違，すなわちフィルター チップ中瀻維の配置構造によって変化した。

List of Symboles

$C$ = Cunningham slip correction factor [-]

$d=$ fiber denier per filament $\left[\mathrm{g} / 9 \times 10^{6} \mathrm{~cm}\right]$

$d_{\mathbf{f}}=$ diameter of fiber in Eq. (2) $[\mathrm{cm}]$

$d_{\mathrm{fm}}=$ modified diameter of fiber in Eq. (4)

(cm)

$g$ =acceleration due to gravity taken as 980 $\left[\mathrm{cm} / \mathrm{sec}^{2}\right]$

$K=$ permeability coefficient $\quad[-]$

$K_{\mathrm{m}}=$ modified permeability coefficient [-]

$k=$ resistance coefficient $\quad[-]$

$L=$ length of filter tip $(\mathrm{cm})$

$l=$ circumference of cross section $[\mathrm{cm}]$

$l_{0}=$ the longest distance of cross section of fiber in Eq. (12) [cm]

$n$ = exponent

$\Delta P=$ pressure drop across filter tip, cm of water column

$[\mathrm{cm}]$

$S=$ specific surface area $\quad\left[\mathrm{cm}^{2}\right]$

$s=$ cross sectional area of fiber $\left(\mathrm{cm}^{2}\right)$

$V=$ volume of filter tip $\left\{\mathrm{cm}^{3}\right\rfloor$

$v=$ superficial velocity $-i$. e., velocity across empty filter area $\quad[\mathrm{cm} / \mathrm{sec}]$

$W=$ weight of filter sample

〔g〕

$x$ = weight fraction in Eq. (5) $\varepsilon_{f}=$ filter porosity

$\left(1-\varepsilon_{\mathrm{f}}\right)=$ packing density of filter $=$ volume fraction of fiber in filter $[-]$

$\eta=v i s c o s i t y$ of air taken as $1.81 \times 10^{-4}$

$[\mathrm{g} / \mathrm{cm} \cdot \mathrm{sec}]$

$\rho=$ density of water taken as $1 \quad\left[\mathrm{~g} / \mathrm{cm}^{3}\right]$

$\rho_{\mathrm{f}}=$ density of fiber

$\left[\mathrm{g} / \mathrm{cm}^{3}\right)$

$\Phi_{\mathrm{f}}=$ shape factor in Eq. (3)

$[-]$

$\phi_{\mathrm{f}}=$ shape factor in Eq. (12)

$[-]$

\section{女支献}

1) U.S. Patent 2,794,239, 日特公, 昭 34-5,749, 日特公, 昭 $34-5.750$

2) U.S. Patent 2,931,364, 日特公，昭 34-5.206， 日特公, 昭 $35-2,052$

3) U.S. Patent 3,418,890, 日特公, 昭 44-18,796

4) D. J. Evans, M. Lipson, R. J. Mayfield, J. Tex. Inst., 66, 325 (1975)

5) 前田和生ほ加, 専売中研䛭, No.116，49（1974）

6) U.S. Patent $3,552,400$

7) 玉置昭道，上原 実，専売中研報，No. 115，45 (1973)

8) 木村典夫，伊井谷鎡一，化学工学，23，792 (1959)

9) C. N. Davies, Proc. Inst. Mech. Eng., 1B (5), 185 (1952)

10) 前田和生, 大西昭男，小林 警，上原 実、昭和 46 年纎維学会秋季研究発表会，講演要旨集，p.126

11) R.M. Werner, L.A. Clarenburg, $I \& E C$. Process Design Develop., 4, 288 (1965)

12) H. W. Piekaar, L. A. Clarenburg, Chem. Eng. Sci, 22, 1,399 (1967)

13) J. Kozeny, Ber. Wien. Akad. 136a, 271 (1927) P. C. Carman, Trans. Inst. Chem. Engs., 15, 150 (1937)

14) 吉岡直哉, 巧見 準, 田森行男，粉体工学， 674 (1966)

15) I. Langmuir, "Report on Smokes and Filters" Section I, U.S. Office of Scientific Research and Development, No. 865, Part IV (1942)

16) C. Y. Chen, Chem. Revs., 55, 595 (1955)

17) 木村典夫，伊井谷鎆一，化学工学，33，1,008 (1969)

18) 標葉二郎，高分子，17，869(1968)

19) W. B. Fordyce, I. W. Hughes, M. G. Ivinson, Tob. Sci., 5, 70 (1961) 